Journal of Computer Science 6 (12): 1490-1493, 2010

ISSN 1549-3636

(C) 2010 Science Publications

\title{
Application of Interline Power Flow Controller to Increase Transient Stability of Power System
}

\author{
Prechanon Kumkratug \\ Division of Electrical Engineering, Faculty of Engineering at Si Racha, \\ Kasetsart University, 199 M.6, Tungsukhla, Si Racha, Chonburi, 20230, Thailand
}

\begin{abstract}
Problem statement: The Interline Power Flow Controller (IPFC) is a novel device which can increase transient stability of power system. To verify the capability of the effect of IPFC on stability improvement of power system, the suitable mathematical model and control strategy of IPFC are needed to be presented. Approach: This study presented the mathematical model and control strategy of IPFC. The multi-series converters of IPFC are represented by multi-series voltage sources with associate transformer leakage reactance. The parameters of IPFC are modeled into power flow equation and thus it is used to determine control strategy. This study used Bang-Bang control strategy. The swing curves of the three phase faulted power system without and with an IPFC are tested and compared in various cases. Results: The swing curve of system without an IPFC get increased monotonically and thus the system can be considered as unstable whereas the swing curves of system with an IPFC can return to stable equilibrium point. Conclusion: The presented model of IPFC can help us to comprehend the effect of IPFC on transient stability improvement of power system. From simulation results, the IPFC can increase transient stability of power system.
\end{abstract}

Key words: Power system stability, transient stability, FACTS devices, interline power flow controller

\section{INTRODUCTION}

Transient stability improvement is one of the important aspects in modern power system. The innovative Flexible AC Transmission System (FACTS) devices have been proposed during the last three decades and provide better utilization of existing systems. There are various forms of FACTS devices such as Static Synchronous Series Compensator (SSSC), Static Synchronous Compensator (STATCOM) and Unified Power Flow Controller (UPFC) (Kumkratug, 2003; Kumkratug and Haque, 2003a; 2003b; Ravichandran et al., 2007; Shayeghi and Abdolalipour, 2009; Nazarpour et al., 2006; Nayeripour and Niknam, 2008).

Interline Power Flow Controller (IPFC) is the newest FACTS devices. It is the innovative combination of two or more series converters which are coupled via DC link. The applications of IPFC to improve damping of the system are reported in (Zhang, 2003; Vasquez-Arnez and Zanetta, 2008). A few researches have applied IPFC to improve transient stability of power system (Parimi et al., 2008; Azbe and Mihalic, 2008; Bhownick et al., 2009). Thus it is needed to further investigate the effect of IPFC on transient stability of power system.
This study presents the mathematical model of power system equipped with an IPFC. The presented mathematical model is applied to design control strategy of an IPFC. This study applies the Bang Bang control to design the control law of an IPFC. The simulation results are tested on a Single Machine Infinite bus system.

\section{MATERIALS AND METHODS}

Interline Power Controllers: Consider IPFC for $n$ converters as shown in Fig. 1. IPFC is the combination of the multi-series converters. The multi series converters are coupled by a common DC link as shown in Fig. 1. The DC link provides a path to exchanges active power between multi-series converters. The series converters inject the series voltages into the transmission lines through transformers.

The power flow through the line can be regulated by controlling the magnitudes and the angles of the converters. The injected voltage magnitudes and angles determine the active and the reactive power into the transmission lines. The converters have a capability of electromechanically generating and absorbing the reactive power. However, without losses of converters, the injected active power must be supplied by the DC link from the AC system. 


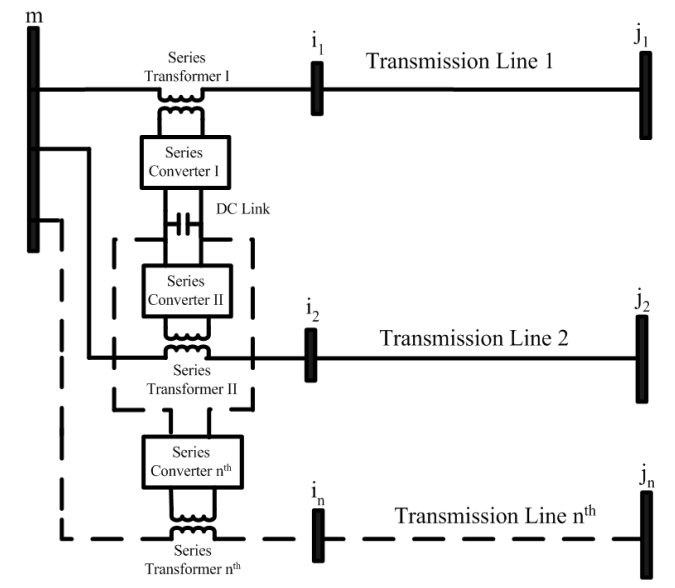

Fig. 1: Schematic diagram of IPFC

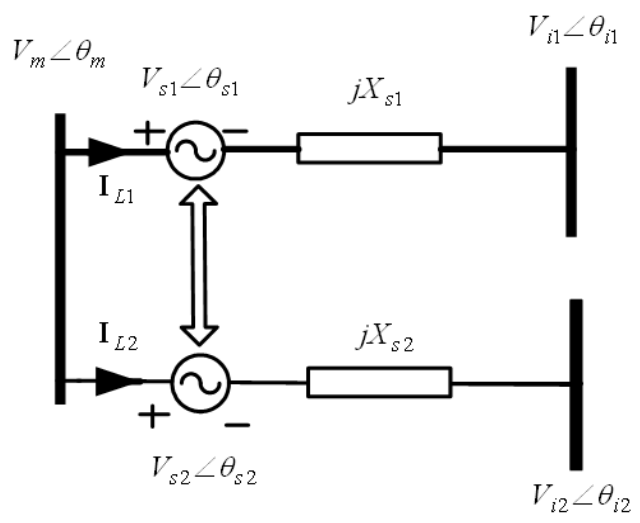

Fig. 2: Representation of an IPFC

Mathematical model: This Section will derive the mathematical model of IPFC. Fig. 2 shows the equivalent circuit of Fig. 1 where IPFC consists of 2 converters. The series converter is replaced by synchronous voltage source $\left(\mathrm{V}_{\mathrm{s}} \angle \theta_{\mathrm{s}}\right)$ in series with the associate transformer leakage reactance $\left(\mathrm{X}_{\mathrm{s}}\right)$.

The complex power of line 1 is given by

$$
\begin{aligned}
\mathbf{S}_{\mathrm{mi}}^{1} & =\mathrm{P}_{\mathrm{mi}}^{1}+\mathrm{j} \mathrm{Q}_{\mathrm{mi}}^{1} \\
& =\mathbf{V}_{\mathrm{m}}\left(\mathrm{I}_{\mathrm{L} 1}\right)^{*} \\
& =\mathrm{V}_{\mathrm{m}} \angle \theta_{\mathrm{m}}\left[\frac{\mathrm{V}_{\mathrm{m}} \angle \theta_{\mathrm{m}}-\mathrm{V}_{\mathrm{sl}} \angle \theta_{\mathrm{s} 1}-\mathrm{V}_{\mathrm{i} 1} \angle \theta_{\mathrm{i} 1}}{\mathrm{jX}}\right]^{*}
\end{aligned}
$$

The active and the reactive powers of line 1 are given by:

$$
\begin{aligned}
\mathrm{P}_{\mathrm{mi}}^{1}= & -\mathrm{b}_{1} \mathrm{~V}_{\mathrm{m}} \mathrm{V}_{\mathrm{s} 1} \cos \left(90-\theta_{\mathrm{s} 1}+\theta_{\mathrm{m}}\right)- \\
& \mathrm{b}_{1} \mathrm{~V}_{\mathrm{i} 1} \mathrm{~V}_{\mathrm{m}} \cos \left(90+\theta_{\mathrm{m}}-\theta_{\mathrm{i} 1}\right)
\end{aligned}
$$

$$
\begin{gathered}
\mathrm{Q}_{\mathrm{mn}}^{1}=\mathrm{b}_{1} \mathrm{~V}_{\mathrm{m}}^{2}-\mathrm{b}_{1} \mathrm{~V}_{\mathrm{m}} \mathrm{V}_{\mathrm{s} 1} \cos \left(90-\theta_{\mathrm{s} 1}+\theta_{\mathrm{m}}\right)- \\
\mathrm{b}_{1} \mathrm{~V}_{\mathrm{i} 1} \mathrm{~V}_{\mathrm{m}} \cos \left(90+\theta_{\mathrm{m}}-\theta_{\mathrm{i} 1}\right)
\end{gathered}
$$

The complex powers of line 2 is given by:

$$
\begin{aligned}
\mathrm{S}_{\mathrm{mi}}^{2} & =\mathrm{P}_{\mathrm{mi}}^{2}+\mathrm{j} \mathrm{Q}_{\mathrm{mi}}^{2} \\
& =\mathrm{V}_{\mathrm{m}}\left(\mathrm{I}_{\mathrm{L} 2}\right)^{*} \\
& =\mathrm{V}_{\mathrm{m}} \angle \theta_{\mathrm{m}}\left[\frac{\mathrm{V}_{\mathrm{m}} \angle \theta_{\mathrm{m}}-\mathrm{V}_{\mathrm{s} 2} \angle \theta_{\mathrm{s} 2}-\mathrm{V}_{\mathrm{i} 2} \angle \theta_{\mathrm{i} 2}}{\mathrm{j} \mathrm{X}_{\mathrm{s} 2}}\right]^{*}
\end{aligned}
$$

The active and the reactive powers of line 2 are given by:

$$
\begin{aligned}
\mathrm{P}_{\mathrm{mi}}^{2}= & -\mathrm{b}_{2} \mathrm{~V}_{\mathrm{m}} \mathrm{V}_{\mathrm{s} 2} \cos \left(90-\theta_{\mathrm{s} 2}+\theta_{\mathrm{m}}\right)- \\
& \mathrm{b}_{2} \mathrm{~V}_{\mathrm{i} 2} \mathrm{~V}_{\mathrm{m}} \cos \left(90+\theta_{\mathrm{m}}-\theta_{\mathrm{i} 2}\right) \\
\mathrm{Q}_{\mathrm{mi}}^{2}= & \mathrm{b}_{2} \mathrm{~V}_{\mathrm{m}}^{2}-\mathrm{b}_{2} \mathrm{~V}_{\mathrm{m}} \mathrm{V}_{\mathrm{s} 2} \cos \left(90-\theta_{\mathrm{s} 2}+\theta_{\mathrm{m}}\right)- \\
& \mathrm{b}_{2} \mathrm{~V}_{\mathrm{i}} \mathrm{V}_{\mathrm{m}} \cos \left(90+\theta_{\mathrm{m}}-\theta_{\mathrm{i} 2}\right)
\end{aligned}
$$

The complex power injected by converter 1 is given by:

$$
\begin{aligned}
\mathrm{S}_{\mathrm{s} 1} & =\mathrm{P}_{\mathrm{s} 1}+\mathrm{jQ}_{\mathrm{s} 1} \\
& =\mathrm{V}_{\mathrm{s} 1}\left(-\mathrm{I}_{\mathrm{L} 1}\right)^{*} \\
& =\mathrm{V}_{\mathrm{s} 1} \angle \theta_{\mathrm{s} 1}\left[\frac{-\mathrm{V}_{\mathrm{m}} \angle \theta_{\mathrm{m}}+\mathrm{V}_{\mathrm{s} 1} \angle \theta_{\mathrm{s} 1}+\mathrm{V}_{\mathrm{i} 1} \angle \theta_{\mathrm{i}}}{\mathrm{j} \mathrm{X}_{\mathrm{s} 1}}\right]^{*}
\end{aligned}
$$
by:

The active power injected by converter 1 is given

$$
\begin{aligned}
& \mathrm{P}_{\mathrm{s} 1}=\operatorname{Re}\left[\mathrm{S}_{\mathrm{s} 1}\right] \\
& =-\mathrm{b}_{1} \mathrm{~V}_{\mathrm{m}} \mathrm{V}_{\mathrm{s} 1} \cos \left(90-\theta_{\mathrm{m}}+\theta_{\mathrm{s} 1}\right)+ \\
& \mathrm{b}_{1} \mathrm{~V}_{\mathrm{s} 1} \mathrm{~V}_{\mathrm{i} 1} \cos \left(90-\theta_{\mathrm{i} 1}+\theta_{\mathrm{s} 1}\right)
\end{aligned}
$$
by:

The reactive power injected by converter 1 is given

$$
\begin{aligned}
\mathrm{Q}_{\mathrm{s} 1}= & \operatorname{Im}\left[\mathrm{S}_{\mathrm{s} 1}\right] \\
= & -\mathrm{b}_{1} \mathrm{~V}_{\mathrm{m}} \mathrm{V}_{\mathrm{s} 1} \sin \left(90-\theta_{\mathrm{m}}+\theta_{\mathrm{s} 1}\right)+ \\
& \mathrm{b}_{1} \mathrm{~V}_{\mathrm{s} 1}^{2}+\mathrm{b}_{1} \mathrm{~V}_{\mathrm{s} 1} \mathrm{~V}_{\mathrm{i} 1} \cos \left(90-\theta_{\mathrm{i} 1}+\theta_{\mathrm{s} 1}\right)
\end{aligned}
$$

Similarly, the active and the reactive powers injected by converter 2 are given by:

$$
\begin{aligned}
\mathrm{P}_{\mathrm{s} 2}=\operatorname{Re}\left[\mathrm{S}_{\mathrm{s} 2}\right] \\
=-\mathrm{b}_{2} \mathrm{~V}_{\mathrm{m}} \mathrm{V}_{\mathrm{s} 2} \cos \left(90-\theta_{\mathrm{m}}+\theta_{\mathrm{s} 2}\right)+ \\
\mathrm{b}_{2} \mathrm{~V}_{\mathrm{s} 2} \mathrm{~V}_{\mathrm{i} 2} \cos \left(90-\theta_{\mathrm{i} 2}+\theta_{\mathrm{s} 2}\right)
\end{aligned}
$$




$$
\begin{aligned}
& \mathrm{Q}_{\mathrm{s} 2}=\operatorname{Im}\left[\mathrm{S}_{\mathrm{s} 2}\right] \\
& =-\mathrm{b}_{2} \mathrm{~V}_{\mathrm{m}} \mathrm{V}_{\mathrm{s} 2} \sin \left(90-\theta_{\mathrm{m}}+\theta_{\mathrm{s} 2}\right)+ \\
& \mathrm{b}_{2} \mathrm{~V}_{\mathrm{s} 2}^{2}+\mathrm{b}_{2} \mathrm{~V}_{\mathrm{s} 2} \mathrm{~V}_{\mathrm{i} 2} \cos \left(90-\theta_{\mathrm{i} 2}+\theta_{\mathrm{s} 2}\right)
\end{aligned}
$$

As mentioned earlier that the active power exchanged between series converters are zeroes. When the losses in IPFC are neglected, the following criterion must be satisfied:

$$
\mathrm{P}_{\mathrm{s} 1}=\mathrm{P}_{\mathrm{s} 2}
$$

It can be seen from the presented equation that the power through the line can be regulated by controlling parameter on an IPFC.

Control strategy: Consider a Single Machine Infinite Bus (SMIB) system as shown in Fig. 3a. An IPFC is placed in the transmission line at point $\mathrm{m}$ to improve stability. Figure $3 \mathrm{~b}$ shows the its equivalent circuit diagram. The equations determining the stability behavior of generator is given by:

$$
\dot{\delta}=\omega
$$

$\dot{\omega}=\frac{1}{\mathrm{M}}\left[\mathrm{P}_{\mathrm{m}}-\mathrm{P}_{\mathrm{e}}\right]$

Here $\delta, \omega, \mathrm{P}_{\mathrm{m}}$ and $\mathrm{M}$ are the rotor angle, speed deviation, input mechanical power and inertia constant. The output electrical power is given by:

$$
\mathrm{P}_{\mathrm{e}}=\mathrm{P}_{\mathrm{mi}}^{1}+\mathrm{P}_{\mathrm{mi}}^{2}
$$

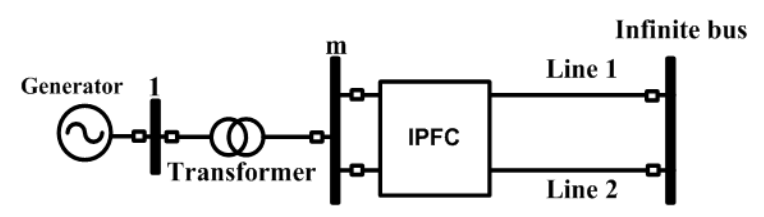

(a)

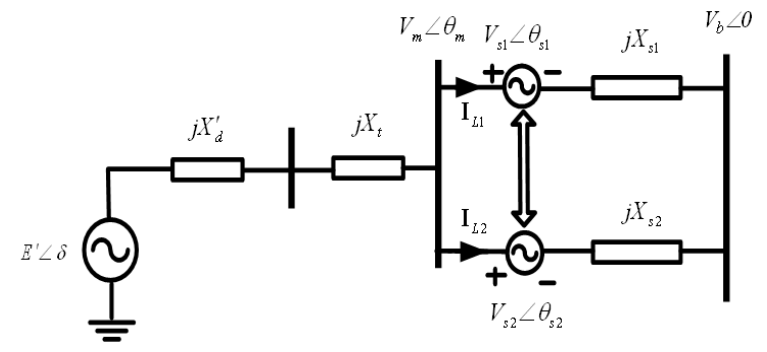

(b)

Fig. 3: Single machine infinite bus system with an IPFC (a) Schematic diagram (b) Equivalent circuit
It can be seen from Eq. 2, 5 and 15 that the output electrical power can be expressed as:

$\mathrm{P}_{\mathrm{e}}=\mathrm{f}\left(\mathrm{V}_{\mathrm{s} 1}, \mathrm{~V}_{\mathrm{s} 2}, \theta_{\mathrm{s} 1}, \theta_{\mathrm{s} 2}\right)$

Equation 14 and 15 clearly indicates that output electrical power of the generator is the main factor determining the stability of the system. The presented mathematical model indicates that stability of the system can be controlled by parameters on IPFC. This study uses the Bang-Bang control strategy to design IPFC control law. When the speed deviation is positive $(\omega>0)$, the $P_{e}$ is raised by controlling parameters on IPFC; When the speed deviation is negative $(\omega<0)$, the $\mathrm{P}_{\mathrm{e}}$ is raised by controlling parameters on IPFC.

\section{RESULTS}

The presented mathematical model and control strategy of IPFC is used to study the effect of IPFC on transient stability improvement of the system of Fig. 3. In all cases, it is considered that a three phase self clearing fault appears at bus $\mathrm{m}$ and the fault is cleared without changing the network configuration. Figure 4 shows the swing curve of the system without an IPFC for clearing time $\left(t_{c l}\right)=144 \mathrm{~m} \mathrm{sec}$. Fig. 5 shows the swings curve of the system with and without an IPFC for $\mathrm{t}_{\mathrm{cl}}=145 \mathrm{~m} \mathrm{sec}$.

\section{DISCUSSION}

From the results in Fig. 4 and 5, we found that the critical clearing time of the system without an IPFC is 144-145 m sec. It can be seen from the Fig. 4 that with fault clearing time $\left(\mathrm{t}_{\mathrm{cl}}\right)=144$, the system is considered as stable and the system is considered as unstable with $\mathrm{t}_{\mathrm{cl}}=145 \mathrm{~m} \mathrm{sec}$ as can been in Fig. 5. However, the system with an IPFC control can stabilize the system with $\mathrm{t}_{\mathrm{cl}}=145 \mathrm{~m} \mathrm{sec}$. The simulation results indicate that an IPFC can improve stability of the system.

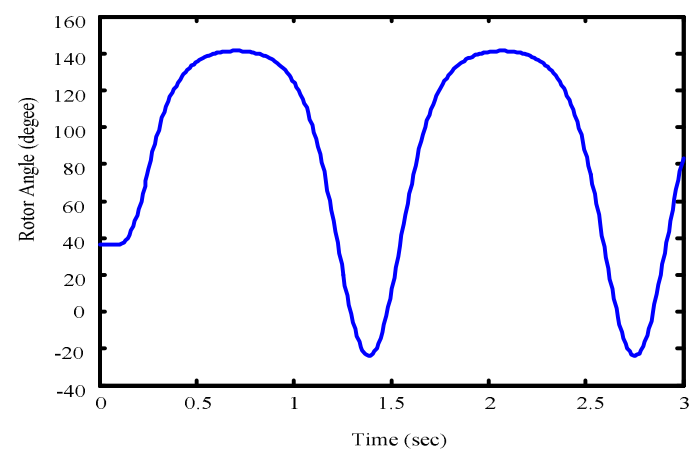

Fig. 4: Rotor angle of the system without IPFC for $t_{c l}=$ $144 \mathrm{~m} \mathrm{sec}$ 


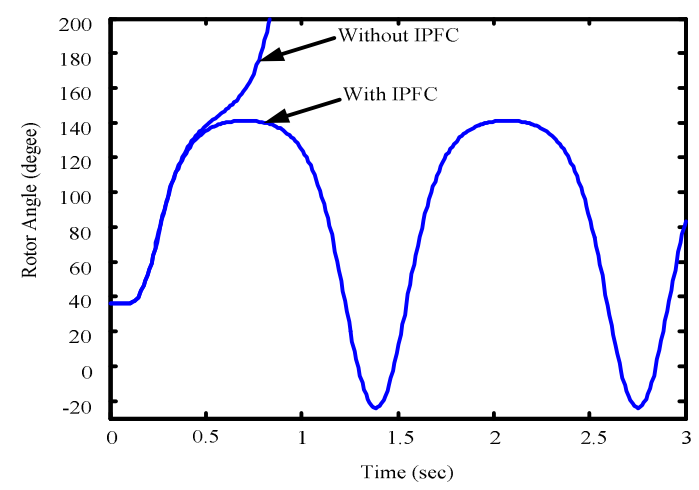

Fig. 5: Rotor angle of the system without and with an IPFC for $\mathrm{t}_{\mathrm{cl}}=145 \mathrm{~m} \mathrm{sec}$

\section{CONCLUSION}

This study investigates the capability of the Interline Power Flow Controller (IPFC) on transient stability improvement of the system. The mathematical model is systematically derived. The presented mathematical model has shown that power flow and stability of system can be regulated by IPFC. This study uses the Bang Bang control to derive its control strategy. The speed deviation is the main factor to decrease and increase power flow of the system. The simulation results are tested on Single Machine Infinite Bus (SMIB) system. From the simulation results, it indicates that an IPFC can improve transient stability of the system.

\section{REFERENCES}

Azbe, V. and R. Mihalic, 2008. The control strategy for an IPFC based on the energy function. IEEE Trans. on Power Syst., 23: 1662-1609. DOI: 10.1109/TPWRS.2008.2004726

Bhownick, S., B. Das and N. Kumar, 2009. An advanced IPFC model to reuse Newton power flow codes. IEEE Trans. Power Syst., 24: 525-532. DOI: 10.1109/TPWRS.2009.2016643

Kumkratug, P., 2003. Versatile model of a unified power flow controller in a simple power system. IEE Proc.-Gener. Transm. Distrib., 150: 155-161. DOI: 10.1049/ip-gtd:20030094

Kumkratug, P. and M.H. Haque, 2003a. Improving damping of a power system by a power system by STATCOM. Proceeding of the Australasian Universities Power Engineering Conference, Sept. 2003, ITEE, New Zealand, pp: 1-5. http://www.itee.uq.edu.au/ aupec/aupec03/papers/ $122 \% 20$ Haque $\% 20$ full $\% 20$ paper.pdf
Kumkratug, P. and M.H. Haque, 2003b. Improving damping and stability region of power system by SSSC. Proceeding of the IEEE Power Engineering Society General Meeting, July 13-17, IEEE Xplore Press, USA., pp: 1710-1714. DOI: 10.1109/PES.2003.1267413

Nayeripour, M. and T. Niknam, 2008. Design of UPFC controller using modified bilinear equation for improving transient stability. Am. J. Applied Sci., 5: 1780-1786.

http://www.scipub.org/fulltext/ajas/ajas51217801786.pdf

Nazarpour, D., S. H. Hosseini and G.B. Gharehpetian, 2006. Damping of generator oscillations using an adaptive UPFC-based controller. Am. J. Applied Sci., $\quad 7: \quad 1662-1668$. http://www.scipub.org/fulltext/ajas/ajas3116621668.pdf

Parimi, A.M., I. Elamwazuthi and N. Saad, 2008. Interline Power Flow Controller (IPFC) Based Damping Controllers for Damping Low Frequency Oscillations in a Power System. Proceeding of the IEEE International Conference on Suitable Energy, Nov. 24-27, IEEE Xplore Press, Singapore, pp: 334-339. DOI: 10.1109/ICSET.2008.4747027

Ravichandran, C.S., S. Subha Rani and T. Manikandan, 2007. Designing of PID controller for discrete time linear system using balanced approach reduced order model. Am. J. Applied Sci., 4: 155-159. http://www.scipub.org/fulltext/ajas/ajas43155-159.pdf

Shayeghi, H. and A. Abdolalipour, 2009. Robust decentralized control of unified power flow controller. Am. J. Applied Sci., 7: 1115-1117. http://www.scipub.org/fulltext/ajas/ajas64736-744.pdf

Vasquez-Arnez, L.R. and L.C. Zanetta, 2008. A novel approach for modeling the steady-state VSC-based multiline FACTS controllers and their constrains. IEEE Trans. Power Deliv., 23: 457-464. DOI: 10.1109/TPWRD.2007.905564

Zhang, X.P., 2003. Modeling of the interline power flow controller and the generalized unified power flow controller in Newton power flow. IEE Proc.Gener. Transm. Distrib., 150: 268-274. DOI: 10.1049/ip-gtd:20030093 